\title{
Can the United States Afford a "No-Fault" System of Compensation for Medical Injury?
}

\section{Citation}

David M. Studdert, Eric J. Thomas, Brett I. W. Zbar, Joseph P. Newhouse, Paul C. Weiler, Jonathon Bayuk \& Troyen A. Brennan, Can the United States Afford a "No-Fault" System of Compensation for Medical Injury?, 60 Law \& Contemp. Probs. 1 (1997).

\section{Published Version}

http://scholarship.law.duke.edu/lcp/vol60/iss2/1/

\section{Permanent link}

http://nrs.harvard.edu/urn-3:HUL.InstRepos:16201736

\section{Terms of Use}

This article was downloaded from Harvard University's DASH repository, and is made available under the terms and conditions applicable to Other Posted Material, as set forth at http:// nrs.harvard.edu/urn-3:HUL.InstRepos:dash.current.terms-of-use\#LAA

\section{Share Your Story}

The Harvard community has made this article openly available.

Please share how this access benefits you. Submit a story.

Accessibility 


\title{
LAW AND CONTEMPORARY PROBLEMS
}

\begin{tabular}{lll}
\hline \hline Volume 60 & Spring 1997 & Number 2 \\
\hline \hline
\end{tabular}

\section{CAN THE UNITED STATESAFFORD A "NO-FA ULT" SY STEM OF COMPENSATION FOR MEDICAL INJURY?}

\author{
DA VID M. STUDDERT, ${ }^{\dagger}$ ERIC J. THOMAS, \\ BRETT I. W. ZBAR, ${ }^{* *}$ JOSEPH P. NEWHOUSE, ${ }^{* * *}$ \\ PAULC. WEILER, ${ }^{* * * *}$ JONATHON BAYUK, \\ AND TROYEN A. BRENNAN ${ }^{\dagger \dagger}$
}

INTRODUCTION

Since the early 1970s, a global debate has been waged about the merits of "no-fault" alternatives to the tort system for compensating victims of medical injury. ${ }^{1}$ Several countries, including Sweden, New Zealand, and Finland, have

Copyright $@ 1997$ by Law and Contemporary Problems

$\dagger$ Instructor in L aw, $\mathrm{H}$ arvard School of Public H ealth

* Instructor in M edicine, $\mathrm{H}$ arvard M edical School.

** Medical Student, $\mathrm{H}$ arvard M edical School.

*** J ohn D. M acA rthur Professor of H ealth Policy and M anagement, $\mathrm{H}$ arvard $\mathrm{U}$ niversity.

**** Henry J. Friendly Professor of Law, H arvard Law School.

***** R esearch A ssistant, $\mathrm{H}$ arvard School of Public H ealth.

t† Professor of Law and Public Health, Harvard School of Public Health; Professor of M edicine, Harvard M edical School.

We are indebted to the R obert Wood J ohnson Foundation for its financial support.

1. See Patricia M. Danzon, Medical Malpractice: Theory, evidence, and Public POLICY (1985); J oshua Fruchter, D octors On Trial: A Comparison of A merican and J ewish L egal A pproaches to M edical M alpractice, 19 A M. J .L . \& MED. 453 (1993); Clark C. H avighurst \& L aurence R. Tancredi, "M edical Adversity Insurance": A No-Fault A pproach to M edical Malpractice and Quality Assurance, 51 MILBANK MEMORIAL FUND Q. 125 (1973); M ichael A. Jones, Medical Injury-The Fault with N o-Fault, 83 PR OF. NE GL. (1987); J effrey O 'Connell, N o-Fault I nsurance for I njuries A rising from M edical Treatment: A Proposal for Elective Coverage, 24 EMORY L.J. 21 (1975); Carl Oldertz, 
moved ahead with implementation of comprehensive no-fault schemes. ${ }^{2}$ The malpractice "crisis" ${ }^{3}$ of the mid-1980s prompted two U.S. states, V irginia and Florida, to introduce limited no-fault compensation systems, wherein victims of severe neonatal injury are compensated for their injury without regard to provider negligence or fault. ${ }^{4}$ In the main, however, the U nited States has persisted with a traditional tort approach, confining compensation of medical injury to instances in which injured patients are able to prove negligence.

O ne of the key issues separating U.S. critics of a no-fault alternative from supporters is its anticipated cost. ${ }^{5}$ Critics argue that the costs of such a system would be prohibitive because its design would necessitate compensation of a much larger pool of victims-not only patients injured by negligent medical care, but patients injured by any medical care. ${ }^{6}$ They find support in two major

The Swedish Patient I nsurance System-E ight Y ears of Experience, 52 M E DICO-L E GA L J . 43 (1983); Sir G eoffrey Palmer, The N inth M onsanto L ecture: The D esign of Compensation Systems: Tort Principles Rule, OK?, 29 V A L. U. L. REV. 1115 (1995); M ichael J. Saks, D o We R eally K now A nything A bout the Behavior of the Tort L itigation System-and Why N ot?, 140 U . PA . L. R E V. 1147 (1992); Carolyn Sappideen, No Fault Compensation for Medical Misadventure-A ustralian Expression of Interest, $9 \mathrm{~J}$. CONTEMP. HeALth L. \& POL'Y 311 (1993); Stephen D. Sugarman, Doing A way with Tort Law, 73 CA L. L. R EV. 555, 558 (1985); Paul C. Weiler, The Case for N o-Fault M edical L iability, 52 M D. L. REV. 908 (1993).

2. For a description of the Swedish scheme, see Patricia M. D anzon, The Swedish Patient Compensation System: L essons for the United States, 15 J. L E G. M E D. 199 (1994); C arl O Idertz, Security Insurance, Patient Insurance, and Pharmaceutical Insurance in Sweden, 34 A M. J. Co M P. L. 635 (1986). For a description of the New Zealand scheme, see Walter Gellhorn, M edical M alpractice L itigation (U.S.)-M edical M ishap Compensation (N.Z.), 73 CoRNELL L. REV. 170 (1988); R ichard S. M iller, An A nalysis and Critique of the 1992 Changes to $\mathrm{N}$ ew Zealand's A ccident Compensation Scheme, $52 \mathrm{M} \mathrm{D}$. L. REV . 1070 (1993). For a description of the Finnish scheme, see Diana Brahams, No Fault Compensation Finnish Style, 332 L A NCET 733 (1988).

3. Increases in claims rates and size of awards caused rapid increases in the cost of medical malpractice insurance and gave rise to fears about availability of medical care in some places. See U.S. General a cCounting Office, Medical Malpra Ctice: Six State Ca Se Studies Show Cla ImS A ND I NSURA NCE COSTS STILL RISE DESPITE REFORMS, GA O/HRD-87-21 (U.S. G.P.O., 1986).

4. See Jill Horwitz \& Troyen A. Brennan, No-Fault Compensation For M edical Injury: A Case Study, 14 HEALTH A FFS., Winter 1995, at 164; M axwell J. Mehlman, Bad "Bad Baby" Bills, 20 A M. J.L. \& MED. 129 (1994); Peter H. White, Innovative No-Fault Tort Reform For an Endangered Specialty, 74 V A . L. REV . 1487 (1988);

5. See R andall R. Bovbjerg, Medical Malpractice: Research and Reform, 79 VA. L. REV. 2155 (1993) (reviewing PA UL C. WeILER ET A L., A MEA SURE OF MALPRA CTICE (1993)).

6. See Maxwell J. Mehlman, SAYING "No" to No-FAult: What the HaRvard MaLpractice Study Means for Medical Malpractice Reform (1991); Elliott M. A bramson, The M edical Malpractice Imbroglio: A Non-A dversarial Suggestion, 78 KY. L.J . 293, 304 (1990); J erry L. M ashaw \& Theodore R. Marmor, Conceptualizing, Estimating, and Reforming Fraud, Waste, and A buse in Healthcare Spending, 11 Y ALE J. ON REG. 455, 486-87 (1994) ("The no-fault scheme has much to recommend it, but it probably would not yield a reduction in the overall costs of medical care. B ecause a much larger percentage of patients experiencing adverse effects would be compensated under such a scheme-albeit at much lower amounts-the total cost of the system might increase. There are currently no good cost estimates for this sort of major malpractice reform."); Thomas B. M etzloff, Understanding the Malpractice Wars, 106 HARV. L. REV. 1169, 1194-95 (1993) (reviewing PAUL C. WEILER, MEDICA L MALPRACTICE ON TRIAL (1991)); Michael J. Saks, M edical M alpractice: Facing Real Problems and Finding Real Solutions, 35 W M. \& M A RY L. REV. 693, 704-05 (1994); Stephen D. Sugarman, D octor N 0, 58 U. CHI. L. REV. 1499, 1516 (1991) (reviewing PA UL C. WEILER, MEDICA L MALPRACTICE ON TRIAL (1991)). 
studies of medical injury, one conducted in California ${ }^{7}$ and the other in New Y ork, ${ }^{8}$ both of which indicate that the vast majority of injured patients never receive compensation for their injuries. Proponents respond by appeals to both equity and efficiency. They agree that many more patients would indeed qualify for compensation under a no-fault scheme, not merely those whose injuries result from negligence and who are both pecunious and sufficiently fortunate to negotiate the tort system effectively. Proponents argue further that cost increases generated by this increased volume of claimants could be offset by significant savings in administrative expenses.

These arguments swirl around a paucity of empirical evidence about the cost of a workable no-fault system. Given widespread apprehension about the cost of the current system, closer attention to this issue is crucial to any serious consideration of a move toward no-fault. The comparative experience of countries that have administrative compensation systems in place can inject important information into the debate in this country. ${ }^{9}$ O bserving how these systems have developed and refined approaches to compensating injury is instructive for A merican consideration of reform. Y et the applicability of overseas experience to the U.S. health care system is a concern. Specifically, differences in wider social insurance arrangements, the price of medical care, and the incidence and cost of medical injuries may well exert unique pressures on the operating costs of a no-fault system in the $U$ nited States.

This article presents results from a study estimating the costs of a no-fault system, one that is similar to the system now in operation in Sweden, within the context of the U.S. health care system. U sing adverse events ${ }^{10}$ that occurred in $U$ tah and Colorado in 1992, we calculated the cost of compensating medical injuries using Swedish criteria, and compared this to the cost of the medical malpractice system. Swedish compensable events ("SCE s") are essentially determined by asking whether the injury suffered could have been avoided. ${ }^{11}$ Sweden's "avoidability" criteria thus occupy a middle ground between the high threshold of injury compensation set by the negligence standard, and the low threshold established by a set of criteria that would simply compensate all iatrogenic injury.

U se of avoidability principles to simplify the compensation inquiry will not be completely foreign to tort scholars in this country: " designated compensable events" ("DCEs") and their later manifestation, "accelerated compensation events" ("A CE s"), employ this general concept as their basis. ${ }^{12}$ DCE s are pre-

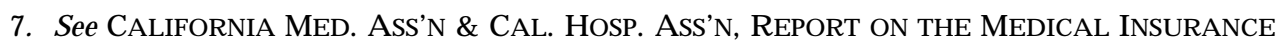
FEA SIBILITY STUDY (1977).

8. Seepaul C. Weileretal., A Measure of Malpractice (1993).

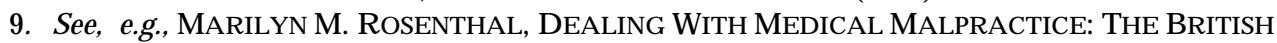
AND SWEDISH EXPERIENCE (1988).

10. A $n$ adverse event was defined as an injury caused by medical management (rather than the disease process) that resulted in either a prolonged hospital stay or disability at the time of discharge.

11. See Carl Espersson, The Swedish Patient Insurance: A Descriptive R eport, 7-9 (A pr. 1992) (paper presented at Balliol College, Oxford, E ngland, on file with author).

12. See Havighurst \& Tancredi, supra note 1 ; Laurence Tancredi \& Randall R. Bovbjerg, Re- 
determined categories of medical injuries that are identified by medical experts as preventable "in a specified share of cases receiving good care." ${ }^{13}$ For example, inadvertent laceration of a woman's bladder during a hysterectomy procedure is the kind of event that may automatically qualify for compensation under this formulaic approach. ${ }^{14}$ Proposals for systematic use of such devices have been termed "selective no-fault." 15 nly those medical injuries selected for coverage by professional judgment are included, ${ }^{16}$ and the association with fault is blurred by use of statistical preventability, rather than individualized judgments, in determining compensation. ${ }^{17}$

The DCE/A CE approach bears some evident similarities to the Swedish approach. Conceptually, both approaches use the notion of avoidability to situate the compensation threshold somewhere between the polar extremes of pure no-fault and fault-based systems. In addition, recognizing the importance of a simple, uniform decisionmaking process to the effective operation of a nofault scheme, ${ }^{18}$ both approaches aim to establish criteria that are more predictable and economical than current inquiries about provider negligence. ${ }^{19} \mathrm{How}$ ever, the Swedish approach differs from the DCE approach in several important ways.

First, the Swedish approach does not rely exclusively on predetermined categorizations of injury, although some such categorizations are not incompatible as a subset of injury types within a Swedish model. Second, a moot issue with the DCE approach is whether it is employed as a selective no-fault program within fault-based malpractice law or used as a special component in a comprehensive no-fault program that bases compensation for events not covered by a DCE upon individualized determinations using other criteria. This question does not arise with Swedish compensable events because the approach is designed to accommodate all medical injury in a more-or-less uniform manner. It is precisely this uniformity that allows cost estimates for a comprehensive no-fault scheme to be made using the Swedish approach.

O ur prior Harvard Medical Practice Study in New Y ork ("the New Y ork study") based cost estimates of no-fault schemes on the assumption that a pure no-fault system-one that compensated all iatrogenic injury-would replace

thinking R esponsibility for Patient Injury: A ccelerated Compensation E vents, A M alpractice and Q uality Reform Ripe for a Test, 54 L A W \& CONTEMP. PR OBS. 147 (Spring 1991).

13. R andall R. B ovbjerg et al., O bstetrics and M alpractice: E vidence on the Performance of a Selective No-Fault System, 265 JAMA 2836 (1991); see also A BA CoMM. ON MED. ProfesSIONAL LIA B., DeSIGNA TEd COMPENSA BLE EVENT SY STEM: A FEA SIBILITY STUdy 8 (1990).

14. See B ovbjerg et al., supra note 13 , at 2837.

15. Seeid.

16. Seeid.

17. See id. at 2841.

18. A . R ussell L ocalio et al., I dentifying A dverse E vents Caused by M edical Care: Degree of Physician A greement in a R etrospective Chart R eview, 125 A N N A LS I NTER NA L M ED . 457 (1996).

19. B ovbjerg et al., supra note 13, at 2842. 
the current tort system. ${ }^{20} \mathrm{~N}$ one has estimated costs using compensation criteria actually applied in countries that operate no-fault systems. U se of these methods can provide a more realistic estimate of the economic feasibility of a nofault compensation scheme in the $U$ nited States.

In Part II, we describe the origins, operations, and claims experience of Sweden's no-fault system. Part III overviews economic pressures faced by three countries-Sweden, New Zealand, and the U nited States- with contrasting medical injury compensation systems. We also describe the strategies pursued in each country to address these pressures. The results of our study of the cost of no-fault compensation systems in $U$ tah and Colorado are presented in Part IV , together with a description of the methods used to obtain our estimates and the limitations to our approach. We conclude by suggesting some policy uses for our findings, and we raise several issues for further consideration.

II

\section{MEDICA L INJURY COMPENSATION IN SWEDEN}

\section{A. Origins}

For the past two decades, Sweden's Patient Insurance Compensation Fund has compensated victims of iatrogenic injury through administrative means, without regard to provider fault. ${ }^{21}$ The Fund was not created to replace an unwieldy or overly expensive tort system. Medical malpractice actions were extremely rare in Sweden- on average, only about ten cases per year resulted in compensation. ${ }^{22} \mathrm{~N}$ or was it the result of a government mandate.

D uring the early 1970s, political leaders became increasingly convinced that the tort system was inadequate as a mechanism for compensating patients who were injured by medical treatment. They charged the Federation of County Councils ("FCC") - an organization that represents Sweden's county councils in their capacity as principal owners and funders of the nation's health care delivery system - with responsibility for working out an alternative. A set of voluntary agreements that form the basis of the compensation scheme emerged from discussions between the FCC and a consortium of Sweden's largest insurance companies. $^{23}$

The Fund operates in the context of one of the most generous and compre-

20. See WEILER ET A L., supra note 8, at 101-09. The New Y ork study did generate cost estimates applying certain quantitative limits to compensability- principally, minimum disability periods. H owever, there was no attempt in the study to estimate costs using qualitative criteria that differed from our basic definition of an adverse event. See supra note 10.

21. See E spersson, supra note 11, at 4-5.

22. See Carl O Idertz, The Patient, P harmaceutical and Security Insurances, in COMPE NSA TION FOR Personal InJURy IN SWEden and OTHER COUNTRIES 51, 55 (Carl Oldertz \& Eva Tidefelt eds., 1988).

23. Interview with Carl Espersson and Lena M anserus, Skandia Insurance Company, Stockholm, Sweden (Sept. 1995). 
hensive social insurance systems in the world. Swedes enjoy three basic tiers of coverage. ${ }^{24}$ A broad social insurance scheme covers all citizens for the cost of their basic medical expenses and lost earnings due to illness or injury, regardless of its cause. Medical benefits include inpatient and outpatient care at public hospitals and clinics, and an approved list of drugs. Workers who sustain injury in the course of employment have these benefits supplemented by coverage from an administrative no-fault scheme, similar to workers' compensation schemes in the $U$ nited States. A collection of smaller schemes comprise a third tier, covering injuries sustained in certain designated circumstances, such as in automobile accidents and sports. The medical injury compensation scheme was initiated as one of these special purpose schemes.

\section{B. Operation}

Pamphlets describing the Fund are made available to all patients treated in Swedish hospitals. If a patient believes that she has been injured as a result of medical care, an application for benefits is made using forms available in all clinics and hospitals. Physicians actively participate in sixty to eighty percent of claims that are made, helping their patients complete and file the relevant forms. ${ }^{25}$ A social worker from the hospital is also available at the patient's request to assist with this task. O nce a claim is made, the treating physician is required to prepare and file a written report on the alleged injury.

A djustors in a central office in Stockholm receive, register, and manage all of the claims, communicating regularly with the patients while their claims are being processed. A fter an initial determination of eligibility has been made, the adjustor forwards the cases for final determination to the specialists selected and retained by the $\mathrm{F}$ und to help judge compensability. The physicians and claims adjustor apply the relevant eligibility criteria (described below) and make a determination about compensation, with the final determination in the hands of the adjustor. The process is relatively fast, with the average claim taking six months from its initiation to final determination. Patients also have the option of a two-step appeals process: the first step consists of a review of the determination by a claims panel; the second step involves an arbitration procedure. Significantly, patients are not precluded from bringing a malpractice action in court against their provider at any stage during or after the claims process. $^{26}$

\section{Determining Compensation}

The F und does not attempt to compensate all injuries caused by medical intervention (or lack thereof). From the outset, planners considered and rejected a range of possible considerations that might have been used to establish rights to compensation (for example, provider fault, unsuccessful or unfortunate re-

\footnotetext{
24. See $D$ anzon, supra note 2 , at 202-03.

25. See E spersson, supra note 11 , at 23 .

26. Seeid.
} 
sults, rare occurrences, relative seriousness, or individual need for compensation.) Instead, in an attempt to delineate a more objective and rational basis for compensation, the $\mathrm{F}$ und chose to make compensation contingent upon the occurrence of an "avoidable" medical injury.

FIGURE 1

DECISION MAKING PROCESS U SING SWEDISH A VOIDABILITY CRITERIA

The key criteria applied in making the avoidability determination are illustrated in Figure 1. D etails of this decisionmaking process are set down in a formal undertaking by the Fund to Swedish health care consumers. While these criteria may appear to be somewhat vague, Fund administrators assert that it has been possible to demarcate the complications that should reasonably be indemnified and those that, because they are unavoidable consequences of a disease or its necessary treatment, should not be indemnified. ${ }^{27}$ This assertion is consistent with our own experience in applying the criteria in this study. It also accords with previous findings that structured implicit judgments regarding the presence of medical injuries are much more reliable than similar judgments of negligence. ${ }^{28}$

27. Seeid. at 9.

28. See Troyen A . B rennan et al., R eliability and Validity of J udgments C oncerning A dverse E vents Suffered by H ospitalized Patients, 27 MED. CARE 1148 (1989). 


\section{FIGURE 1}

Decision Making Process Using SWedish Avoidability CRITERIA

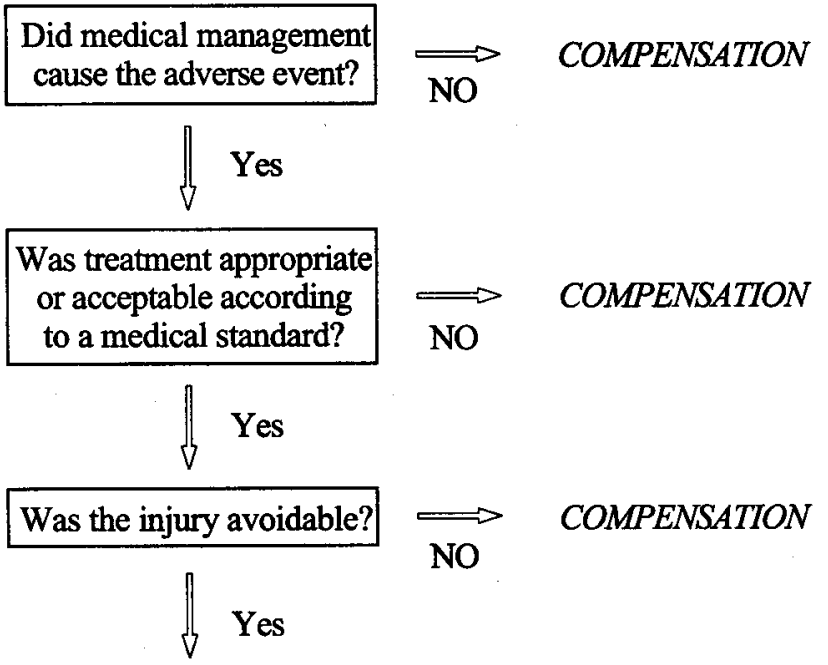

NO COMPENSATION 
FIGURE 2

HIERARCHY OF COMPENSABLE EVENTS

The ambit of compensability in Sweden thus stops well short of covering all injuries caused by medical care. In fact, the tag "no-fault" is somewhat misleading because the central notion of "avoidability" is actually interpreted quite differently. ${ }^{29}$ Figure 2 illustrates the relationship between Swedish compensable events, pure no-fault criteria for compensation, and the negligence standard applied in a standard tort system. Figure 3 provides examples of Swedish judgments on several injuries in the fields of obstetrics and general surgery. Comparison of the Swedish judgments with the adverse event determination (as might be applied in a pure no-fault approach) demonstrates that the avoidability criteria set a higher threshold for compensation. More practical evidence that avoidability imports a higher threshold than pure no-fault can be found in the non-trivial failure rate of claims in Sweden. ${ }^{30}$ In addition, it should be noted that the $F$ und enforces an injury threshold: B efore a patient is eligible for compensation, he or she must have spent at least ten days in the hospital or endured more than thirty sick days. This injury threshold is clearly designed to channel available funds into the hands of the more seriously injured patients.

29. D anzon, supra note 2 , at 200 .

30. Fifty-three percent of the injuries reported up to D ecember 31, 1996, were not compensated. $\mathrm{M}$ ajor reasons for injuries not being compensated were the following: injury was not caused by treatment and/or was a consequence of the underlying disease ( $17 \%)$; injury was unavoidable (24\%); injury was minor ( $10 \%)$; cost of the injury should be paid by another insurance source ( $8 \%)$; claim barred by statute of limitations (7\%); non-compensable accidental injury (4\%); injured did not maintain claim $(4 \%)$; non-compensable infection (4\%); non-compensable incorrect diagnosis ( $9 \%$ ). 


\section{FIGURE 2}

\section{HIERARCHY OF COMPENSABLE EVENTS}

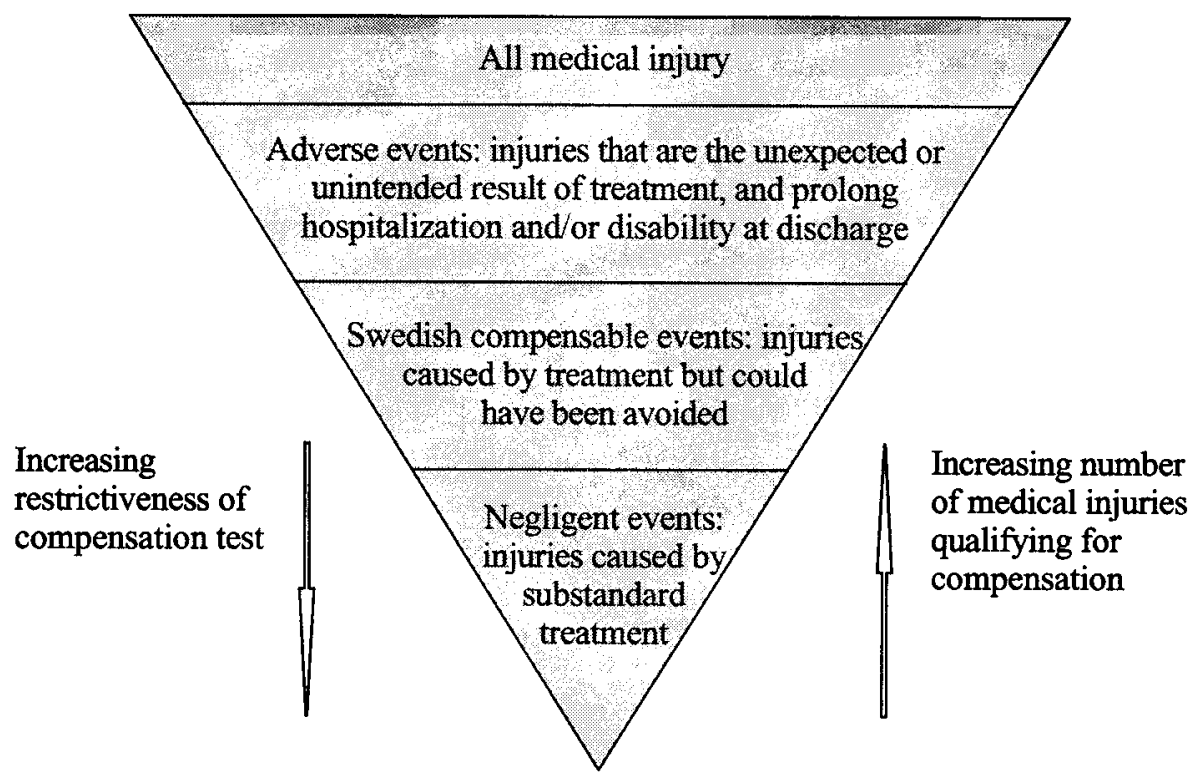


FIGURE 3

EXAMPLES OF SWEDISH AND A DVERSE EVENT JUDGMENTS

\begin{tabular}{|c|c|c|c|c|}
\hline & & & Swedish Compensable & A dverse $\mathrm{E}$ vent \\
\hline \multicolumn{5}{|l|}{ O bstetrics: } \\
\hline \multirow[t]{2}{*}{ IU D Perforation } & $<1 Y$ & Post Insert & Y es & Y es \\
\hline & $>1 Y$ & Post Insert & No & Y es \\
\hline \multicolumn{3}{|c|}{ Perforated U terus In A bortion } & Y es & Y es \\
\hline \multirow{2}{*}{\multicolumn{2}{|c|}{ C-Section Wound Infection }} & $<12$ Hours & Y es & Y es \\
\hline & & $>12 \mathrm{H}$ ours & No & Yes \\
\hline \multicolumn{5}{|l|}{ G eneral Surgery: } \\
\hline \multicolumn{3}{|c|}{ A ngiography I njuries } & No & Y es \\
\hline \multicolumn{3}{|c|}{ CVA Following Catheterization } & No & Yes \\
\hline \multicolumn{3}{|c|}{ CVA Following CA BG } & No & Yes \\
\hline
\end{tabular}

D. System Costs and Performance D ata

The Fund expended 195 million Swedish krona (\$U S28 million) on compensation in 1996, serving a population of 8.75 million people. County councils raise their contributions through taxation and contribute to the Fund on a per capita basis. Payments to successful claimants are made on a periodic basis, as health care and other costs are incurred, although annuities may be set up in some cases. A dministrative costs of operating the system account for approximately eighteen percent of the $F$ und's budget.

The F und has received 99,206 claims since its inception through $D$ ecember 31, 1997, forty-two percent of which have resulted in compensation. Table 1 summarizes the disposition of these claims. The number of claims filed annually has increased over the twenty-two years of the Fund's operation, although the proportion of claims that have been compensated has remained fairly constant. A verage and total compensation levels also have increased steadily despite the adoption of a variety of strategies aimed at curbing the growth in costs. ${ }^{31}$ Through December 30, 1997, 5,500 claims had been appealed to the claims panel, and one-tenth of these have resulted in changed decisions. ${ }^{32}$ A bout ninety of these appealed cases have gone on to arbitration. ${ }^{33}$

31. See infra notes $41-46$ and accompanying text.

32. Interview with Carl Espersson and L ena M anserus, Skandia Insurance Company, Stockholm, Sweden (Sept. 1995).

33. Seeid. 
TABLE 1

SWEDISH CLA IMSEXPERIENCE, 1990-1997**

\begin{tabular}{lccccc}
\hline Y ear & $\begin{array}{c}\text { Claims } \\
\text { Filed }\end{array}$ & $\begin{array}{c}\text { Claims Compen- } \\
\text { sated (\%) }\end{array}$ & $\begin{array}{c}\text { Claims U nder } \\
\text { Investigation* }\end{array}$ & $\begin{array}{c}\text { A verage com- } \\
\text { pensation } \\
\text { (SE K) }\end{array}$ & $\begin{array}{c}\text { Total } \\
\text { compensation } \\
\text { (SE K million) }\end{array}$ \\
\hline $1975-92$ & 62,980 & $25,606(41)$ & 0 & 42,200 & 1,415 \\
1993 & 6,436 & $2,762(43)$ & 2 & 54,000 & 125 \\
1994 & 7,320 & $2,957(40)$ & 0 & 60,000 & 162 \\
1995 & 7,374 & $3,229(44)$ & 1 & 62,000 & 180 \\
1996 & 7,321 & $3,200(44)$ & 112 & 63,000 & 195 \\
1997 & 7,775 & $3,621(47)$ & 2390 & - & - \\
Total & 99,206 & $41,375(42)$ & 2505 & $47,300^{\wedge}$ & $2,087^{\wedge}$ \\
\hline
\end{tabular}

* Includes claims still under investigation on D ecember 31, 1997.

** A significant proportion of the claims compensated in a given year refer to claims filed in the previous year, as is evident from the number of claims under investigation in 1997.

${ }^{Y}$ These totals do not include administrative expenses. In 1996, administrative expenses were approximately 35 million SE K.

1975-1996

Sixty percent of the Fund's compensation is directed toward non-economic losses (that is, pain and suffering). This large proportion can be explained by the extensive social insurance system that Sweden has in place for other kinds of loss. Twenty percent of compensation replaces lost income, and approximately ten percent meets out-of-pocket medical expenses-mainly, deductibles associated with physician fees and certain forms of rehabilitation not covered by social insurance.

\section{COST CONTR OL IN MEDICA L INJURY COMPENSA TION}

A Ithough Sweden's compensation scheme is structurally unique, it has faced a number of the same challenges that have confronted medical injury compensation schemes in other countries-both other administrative compensation systems, such as the scheme in operation in N ew Zealand, and faultbased regimes, such as the U .S. tort system. M ost notably, medical injury compensation systems of various kinds face significant pressures to control costs. The degree of international uniformity in strategies adopted to deal with these pressures is noteworthy. In short, legislators, courts, and tribunals have generally responded to the rising costs of compensation by restricting the circumstances in which claims may be made, narrowing compensation criteria, and setting upper limits on award levels.

In this section, we describe strategies adopted to control costs of medical injury compensation in Sweden, New Zealand, and the U nited States. While the similarity in approaches to reform across these different systems is appar- 
ent, our interest in them is driven by several other considerations. The reforms demonstrate ways in which no-fault systems are able to implement their own versions of the same cost containment strategies adopted widely within the $U$ nited States. They also demonstrate that the trade-off between system cost and patient access to reasonable compensation is not peculiar to the tort system; it is a multinational, as well as multisystem concern. However, concerns about restrictions on access to compensation must be heightened in the U.S. medical malpractice system, where the linkage between worthy patients and satisfactory compensation is al ready suspect. ${ }^{34}$

\section{A. Sweden}

The Swedish scheme was in the midst of significant reform during our visit in September 1995. A fter joining the European U nion in J anuary 1995, the need for Sweden to conform to strict, new antitrust rules ${ }^{35}$ meant the scheme could no longer continue to be administered by a consortium of Swedish insurance companies. O perations relating to treatment injuries within the county councils' health care system were consolidated into a single company, County Council M utual Insurance Company ( $C$ CMIC"), which was established by the FCC. Claims management functions are now outsourced to PSR, a firm owned jointly by CCM IC, and two insurance companies, Folksam and Skandia. ${ }^{36}$

E conomic pressures in the Swedish economy are prompting other changes in the design and operation of the scheme. Sweden has the highest tax rates and the largest public sector of any country in the $O$ rganization of E conomic Cooperation and Development ("OECD"). ${ }^{37}$ Contributions to social welfare benefits account for thirty-three percent of salaries paid out and approximately twenty-three percent of the public sector's overall income. ${ }^{38}$ Thus it is not surprising that major reforms introduced recently to revitalize the Swedish economy have targeted benefits that are available through the nation's mix of social insurance programs. ${ }^{39}$ For example, a one-day waiting period was introduced to limit costs of Sweden's sickness benefits program. In addition, in 1993, the level of benefits available under the program was reduced from ninety percent to eighty percent of the previous salary. In 1996, it was reduced further to 75 percent. $^{40}$

34. See A. R ussell Localio et al., Relation B etween $M$ alpractice Claims and A dverse $E$ vents $D$ ue to N egligence: Results of the Harvard M edical Practice Study III, 325 N E W E N G. J. M E D. 245 (1991).

35. See G overnment to A pprove N ew A ntitrust L egislation, EUROWATCH, July 10, 1992; Sir Leon Brittan, Competition in Europe in 1993, A ddress at the Swedish E mployer's Conference on the EC and the Public Sector (N ov. 26, 1991) (on file with authors).

36. See supra note 32 .

37. See Sven-Olof Lodin, The Swedish Tax System and Inverted Imputation, 36 EUR. TAX'N (IBF D) ๆ 3 A ug. 1, 1996.

38. Seeid.

39. See, e.g., Ilene R . Zeitzer, R ecent E uropean Trends in D isability and R elated Programs, 57 So C. SEC. BULL. 21 (1994); R oger Cohen, E urope's Recession Prompts N ew L ook A t Welfare Costs, N.Y. TIMES, A ug. 8, 1993; Howard LaFranchi, Sweden Trims Vaunted Safety Net, CHRISTIAN SCI. MONITOR, May, 5, 1993: 8.

40. Telephone Interviews with Lena M anserus, Claims M anager, PSR (O ct. and Dec. 1997); un- 
The Patient Insurance Compensation Fund has undergone similar reforms. The most recent example is legislation enacted by the Swedish Parliament in June 1996, in an effort to reign in Fund expenditures. ${ }^{41}$ One provision in the legislation replaces the scheme's injury thresholds with thresholds linked to the level of damages awarded in compensable claims (in other words, a "deductible" amount). The relevant provision states that "a sum equal to onetwentieth of the base sum applicable according to the National Insurance A ct (1962: 381) shall be deducted when the compensation is determined." 42 The "base sum" is a unit amount that allows funds that are redistributed by Sweden's various social insurance schemes to be adjusted annually for inflation. In 1997, the base sum was 36,300 SEK (\$U S5,220), hence a deductible of approximately 1,820 SE K ( $\$$ U S238) was levied upon every injury compensated by the $\mathrm{F}$ und in that year, effectively removing minor injuries from the ambit of the scheme. A nother provision in the new legislation imposes an upper limit on damages (in other words, a "cap"). ${ }^{43}$ The cap is set at 200 times the base sum for each "Ioss event" (\$US1 million) and 1,000 times the base sum (\$U S5.4 million) when multiple "loss events" result from a single injury. In the mid1980 's, categories of compensable injury were narrowed by changing certain medical eligibility criteria. For example, wound infections had been compensated from the outset of the program.

A different approach to controlling Fund expenditures in Sweden seeks to limit the volume of compensable injuries using medical eligibility criteria. W ound infections, for example, have been compensated from the scheme's outset. H owever, adjustors have become strict about the type of infections that are eligible, specifying that infections caused by a patient's own bacteria do not meet avoidability criteria and will not be compensated. ${ }^{44}$ In effect, this removes "dirty" wound infections from consideration. Because wound infections already account for a substantial proportion of claims- nineteen percent of all injuries compensated between 1975 and $1991^{45}$ - this change significantly reduces the system's minor injury costs. ${ }^{46}$

Fund administrators in Sweden explained that an overriding consideration in efforts to control costs through eligibility and benefit reductions is the need to recognize the interconnectedness of social insurance schemes in Sweden. ${ }^{47}$ B ecause medical injury compensation has hitherto assumed a "top-up" function in relation to compensation provided through other schemes, reduction of

published data from PSR on file with authors.

41. The Patient Damages A ct of 1997. (Copy translated by Skandia Insurance Company on file with authors).

42. Id. $\S 9$.

43. See id. $\S 10$.

44. See supra note 32.

45. See E spersson, supra note 11 , at 33 .

46. Seeid.

47. Seeid. 
benefits across these other schemes necessitates increased outlays from the Fund unless commensurate changes are introduced. ${ }^{48}$ D espite a very different approach to medical injury compensation in the U nited States, the Swedish predicament has obvious parallels. O ne response in the $U$ nited States has been modification of the collateral source rule, ${ }^{49}$ an important reform undertaken as part of strategies to reduce medical malpractice costs during the 1970 s and 1980s. ${ }^{50}$

\section{B. New Zealand}

N ew Z ealand's system of social welfare benefits is limited in comparison to Sweden's. ${ }^{51}$ A Ithough citizens do enjoy workers' compensation, ${ }^{52}$ a system of universal health insurance coverage, ${ }^{53}$ and a mixture of public and employerbased disability benefits, ${ }^{54}$ coverage from these sources is neither as generous nor as comprehensive as in Sweden. ${ }^{55}$ L ike Sweden, however, the tort system in $\mathrm{N}$ ew Zealand saw few malpractice suits against medical practitioners prior to enactment of the A ccident Compensation A ct in $1972,{ }^{56}$ the legislation that established New Zealand's no-fault compensation scheme. ${ }^{57}$ A s one commentator remarked of the environment in which no-fault appeared, it was not one of "claims consciousness." ${ }^{58}$

Impetus for the A ct was a series of recommendations from a national inquiry into workers' compensation by Supreme Court J ustice Sir O wen Wood-

\footnotetext{
48. See supra note 32 .

49. The collateral source rule is a common law doctrine that prohibited defendants from submitting evidence regarding compensation or reimbursement received by patients from other sources for their injury. Some states, such as California, simply overturned the collateral source rule. 0 thers created a discretionary offset. A number of less populous states required that any benefits from collateral sources be subtracted from judgments. See TROYEN A. BRENNAN \& DONALD M. BERWICK, NEW Rules: Regulation, Markets, and the Quality of American Health Care 187 (1996); PAUL C. WEILER, MEDICA L MALPRA CTICE ON TRIAL 31-32 (1991).

50. See infra notes 79-81 and accompanying text.

51. See M argaret A. M cG regor V ennell, M edical injury compensation under the $\mathrm{N}$ ew Z ealand A ccident Compensation Scheme: an assessment compared with the Swedish Medical Compensation Scheme, PR OF. NE G. 141 (Sept./O ct. 1989).

52. Seeid. at 142.

53. Seeid.

54. See id. at 143 .

55. See id. at 152 . (1982).

56. N.Z. Stat. 521 (1972), amended by The A ccident Compensation A ct, 1982, 3 N.Z. Stat. 1552

57. See $V$ ennell, supra note 51.

58. Geoffrey Palmer, Compensation for incapacity: A Study of law and SOcial CHANGE IN NEW ZEALAND AND A USTRALIA 43 (1979):

Suing doctors seems to be a peculiarly A merican common law preoccupation. In the jurisdictions of the B ritish Commonwealth there has been little indication of any upsurge in litigation against doctors and hospitals. In New Zealand, for example, in 1970 there were no more than "60 arguably serious medical malpractice claims" and the total payout from insurance companies was $\$ 150,000$. H ospitals in the same period paid out no more than $\$ 35,000$. Premiums for New Zealand doctors ranged between $\$ 17$ and $\$ 28$ per year in 1970 . The key variable, one supposes, is not the amount of medical malpractice but the degree of claims consciousness in the community where it occurs.
} 
house. ${ }^{59}$ The W oodhouse R eport proposed radical change, including the abolition of tort liability for personal injury of all types because it afforded rights to compensation based not on need but on whether a person was covered by an existing scheme or was fortunate enough to succeed in a common law claim. The R eport suggested that a comprehensive scheme for injury compensation should be established to replace the existing tort system and that a scheme should be designed to cover all persons without regard to fault, with benefit levels related to earnings.

These recommendations were largely encompassed by the new legislation. In the idealism of the moment, however, little thought was given to the scope of the scheme and, in particular, to the range of injuries that were to be covered under the A ct's central formula for compensable injury-" personal injury by accident." ${ }^{60}$ Clarifying amendments made it clear that medical injuries were covered by listing "medical misadventure" as a species of injury for which the A ct provided relief, although this term was not clearly defined, and considerable uncertainty has attended its application to claims. ${ }^{61}$

$\mathrm{N}$ ew Z ealand's no-fault accident compensation system faced annual cost increases (above inflation rates) of approximately sixteen percent per year during the late $1980 \mathrm{~s}^{62}$ This growth was explained, in part, by the need to establish reserves that had been run down in the early 1980s and also by the shift to a "payas-you-go" system. However, a range of other factors also were implicatedfor example, increased wage rates, rising hospital expenditures, and high rates of unemployment. ${ }^{63} \mathrm{~N}$ ew Zealand has seen three successive versions of its injury compensation legislation, with the most radical overhaul occurring in 1992. ${ }^{64}$ O ne feature of the 1992 changes was the amendment of key definitional features in the compensation criteria applied to claims. In the medical injury area, the new legislation sought to make the term "medical misadventure" more precise, thus avoiding the "widely varying interpretations" ${ }^{65}$ to which the term had been subjected. ${ }^{66}$ It stipulated that only quantifiably rare adverse consequences of treatment would be compensated. ${ }^{67}$ A nother reform narrowed to

59. See id. at 22-30.

60. See id. at 59-74.

61. See, e.g., A ccident Compensation Comm'n v. A uckland Hosp. Bd. [1980] 2 N.Z.L.R. 748; M acD onald v. A ccident Compensation Corp. [1985] 5 N.Z.A .R . 276; V iggars v. A ccident Compensation Corp. [1986] 6 N.Z.A .R. 235; Polansky v. A CC [1990] N.Z .A .R . 481.

62. See Sir K enneth K eith, "A Iternative R eform O ptions," A ccident Compensation R eform Conference: A Fairer Scheme or a B reach of Contract?, I PSO Conference, W ellington, O ct. 11, 1991, quoted in I A N B. CAMPBELL, COMPENSATION FOR PERSONAL INJURY IN NEW ZEALAND 176 (1996).

63. See CAMPBELL, supra note 62 , at $174-80$.

64. See Miller, supra note 2 , at 1071.

65. See H on W. F. Birch, A ddress to A ccident Compensation R eform Conference: A Fairer Scheme or a Breach of Contract?, IPSO Conference, W ellington, Oct. 11, 1991, quoted in CAMPBELL, supra note 62 , at 111 .

66. See A ccident Compensation A ct, 1982, 3 N .Z. Stat. 1552 § 26(1) (1982)

67. The A ccident Rehabilitation and Compensation Insurance A ct of 1992 defines a "medical mishap" for purposes of determining whether a claim is compensable as "an adverse consequence of treatment by a registered health professional," provided the adverse consequence is both "rare" and "severe." 3 N.Z. Stat. $1552 \S 5(1)$. The A ct continues: “... the adverse consequence shall be rare only 
twelve months the time within which claims had to be lodged after an injury had occurred. ${ }^{68}$

The 1992 reforms have also sought to curtail demand for medical and hospital services. The injured recipient of compensation is now required to undergo periodic physical assessments after compensation has been awarded; when the injured person's capacity for work is determined to be at eighty-five percent or higher, compensation is terminated. ${ }^{69}$ R egulations introduced in 1991 also reduced by fifteen percent the maximum amounts payable by the compensation authority for medical expenses. ${ }^{70}$ In addition, there is growing interest in costsharing arrangements as a way to contain costs by directing medical care expenditures to more severely injured claimants. A s one commentator noted: "There has always been much discussion concerning the vast number of minor claims, an aspect not peculiar to accident compensation. Statistics compiled under the workers' compensation regime indicate that only half of the claims were in respect of absence from work of more than one week." ${ }^{71}$

Finally, reforms have also tackled the issue of non-economic damages. ${ }^{72}$ In addition to wage loss and medical expenses, the New Zealand scheme had previously awarded lump sum compensation for loss of bodily functions, ${ }^{73}$ pain and suffering, ${ }^{74}$ and loss of enjoyment of life. Compensation for these losses had spiraled and, by 1991, accounted for substantially more than medical and hospital treatment expenses combined. L ump-sum compensation for non-economic loss was abolished in the 1992 reforms, and replaced by an "independence allowance" that is available only in cases in which the claimant's injury has resulted in a degree of disability of ten percent or more. A thirteen-week threshold period is also applied before the entitlement is available. ${ }^{75}$

C. U nited States

The cost of medical malpractice represents only a small proportion of total

if the probability is that the adverse consequence would not occur in more than one percent of cases where that treatment is given." Id. § 5(2). (A dverse consequences of treatment are defined to be "severe" if they cause death, hospitalization for more than 14 days, significant disability lasting more than 28 days, or if the injured person qualifies for an "independence allowance.") Id. § 5(4).

68. See CAMPBELL, supra note 62 , at 136 (also noting that this restriction was somewhat eased by the A ccident R ehabilitation and Compensation Insurance A mendment A ct of 1995 , which allowed the compensation authority a measure of discretion in accepting claims not filed within the new 12-month limitation period).

69. See id. at 122-23.

70. See id. at 137.

71. Seeid. at 136.

72. For a comprehensive discussion of the changes to non-economic loss provisions, see Palmer, supra note 1 , at $1149-59$.

73. U p to a maximum of $\$ N Z 17,000$. See A ccident Compensation A ct, 1982, 3 N.Z. Stat. $1552 \S$ 78(1) (1982).

74. Up to a maximum of $\$ N Z 10,000$. See id. $\S 79(1)$.

75. For a discussion of these changes, see CAMPBELL, supra note 62 , at 119-27. 
health-care expenditures in the U nited States, ${ }^{76}$ even allowing for the costs of hospital self-insurance and additional health care services attributable to "defensive medicine." creases in costs and severity of claims, instability in malpractice insurance markets, and resultant concerns about access to medical care have prompted introduction of reforms in all states. ${ }^{78}$

These legislative initiatives are reviewed extensively elsewhere, ${ }^{79}$ and we do not propose to describe them in detail here. A mong the most commonly implemented tort reforms are statutory caps on attorney fees and damages available to plaintiffs, ${ }^{80}$ periodic payment arrangements, and offset of awards against collateral sources of compensation or reimbursement received for the injury. O ther approaches that were implemented during the 1970s and 1980s included shortened statute of limitations periods, mandatory screening panels, and judicial modification of malpractice doctrine to make it more difficult for plaintiffs to file or to win tort actions.

The various packages of tort reform introduced across all fifty states have had a significant impact. Epidemiological studies have demonstrated that changes in liability rules are associated with decreases in both claims rates and premiums. $^{81}$ In the aggregate, claims rates fell nationwide, with annual claims per 100 physicians decreasing from a high of nearly seventeen in 1987 to a low of eleven in $1991 .^{82}$ A vailable evidence suggests that this decrease cannot be attributed to changes in the underlying rate of medical injury due to negligence. ${ }^{83}$ D espite (or perhaps because of) the apparent success of tort reforms in controlling the volume of malpractice litigation, their adoption has continued unabated through the 1990s, at both federal and state levels. ${ }^{84}$

Widespread implementation of the above reforms has deepened concern among a number of commentators in the $U$ nited States about the accessibility

76. Robert W. Sturgis, Tort Cost Trends: A n International Perspective 1 (1992).

77. U.S. Congress, Off. TeCh. A sSessment, Defensive Medicine \& Medical MalPRA CTICE (1994); K enneth J ost, Still Warring O ver M edical M al practice: Time for Something B etter, 79 A.B.A. . . 68, 71 (M ay 1993).

78. See J ost, supra note 77 , at 71 .

79. See, e.g., WEILER, supra note 49, at 17-69; R andall R. Bovbjerg, L egislation on M edical Malpractice: Further Developments and a Preliminary Report Card, 22 U.C. D A VIS L. REV . 499 (1989); Larry Stephen M ilner, The Constitutionality of M edical Malpractice L egislative Reform: A National Survey, 18 L oY. U. CHI. L.J 1053 (1987); Shirley Q ual, A Survey of Medical Malpractice Tort Reform, 12 W M. MitcheLL L. REV. 417 (1986); Glen O. Robinson, The Medical Malpractice Crisis of the 1970's: A Retrospective, 49 L A W \& CONTEM P. PR OBS. 5 (Spring 1986); J oseph Sanders \& Craig J oyce, "Off to the Races": The 1980s Tort Crisis and the L aw R eform Process, 27 H OU S. L. R EV. 207 (1990).

80. The constitutionality of the limit on non-economic damages was upheld in Fein v. Permanente Med. Group, 695 P.2d 665, 680 (Cal. 1985) (en banc). See A MERICAN MED. A Ss'N, A MA TorT REFORM COMPENDIUM (1989) (reporting that between 1985 and 1989, 21 states adopted caps on noneconomic damages).

81. SeeBRENNAN \& BERWICK, supra note 49 , at 189.

82. Seeid.

83. See Eric J. Thomas et al., Incidence of and Risk Factors for A dverse $E$ vents and Negligent Care in $U$ tah and Colorado in 1992 (1997) (unpublished manuscript on file with authors).

84. SeeBRENNAN \& BERWICK, supra note 49 , at 189. 
and adequacy of compensation for victims of medical injury. ${ }^{85}$ A Ithough a significant body of research has addressed the question of the effect of these reforms on frequency and severity of claims, ${ }^{86}$ little is known about their effect on the ability of victims of negligence to obtain compensation. M ore generally, a number of studies have documented that injuries attributable to negligence occur frequently, ${ }^{87}$ and that these injuries are seldom compensated by the tort system. $^{88}$ It is reasonable to conclude that, by raising the obstacles to litigation, tort reforms in the $U$ nited States have further diminished the capacity of the malpractice system to compensate injury.

The crudity of specific tort reforms introduced in the $U$ nited States has also attracted criticism from academic, political, and judicial circles. ${ }^{89}$ For example, commentators have noted the inherently regressive nature of caps on damages, particularly for pain and suffering. ${ }^{90}$ Such caps give rise to vertical inequity among plaintiffs by imposing their limits only upon the damages awarded to the most severely injured victims. ${ }^{91}$ By contrast, the reforms we examined abroad have tackled the problem from the other direction. Sweden's disability thresholds and New Zealand's termination of compensation for injured victims who have retained eighty-five percent of their work capacity are clearly the result of policy decisions to reduce the total costs of compensation by channeling available funds into the hands of the most seriously injured patients.

It is overly simplistic, however, to conclude that adoption of these kinds of reforms in administrative compensation systems abroad is simply a consequence of more enlightened governmental policies. The diffuse nature of medical malpractice in the U nited States- exemplified by random claiming be-

85. U.S. CONGRESS, OFF. TECH. A SSE SSMENT, supra note 77, at 26; Frank P. G rad, M edical Malpractice and the Crisis of Insurance A vailability: The Waning O ptions, 36 CA SE W. RES. L. REV . 1058 (1986); H oward A . L earner, R estrictive M edical M alpractice Compensation Schemes: A Constitutional "Quid Pro Quo" A nalysis to Safeguard Individual Liberties, 18 HARV. J . LEGIS. 143 (1981); E. H aavi M orreim, C ost Containment and the Standard of M edical Care, 75 CA L. L. R EV . 1719, 1738-42 (1987).

86. See, e.g., E. K athleen A dams \& Stephen Zuckerman, Variation in the G rowth and Incidence of Medical Malpractice Claims, 9 J. HEALTH POL. POL'Y \& L. 475 (1984); Patricia Danzon, The Frequency and Severity of M edical Malpractice Claims, 27 J. L. E CoN. 115 (1984); Frank A. Sloan et al., Effects of Tort Reforms on the Value of Closed Medical Malpractice Claims: A Microanalysis, $14 \mathrm{~J}$. HEA LTH POL. POL'Y \& L. 663 (1989); W. K ip V iscusi \& Patricia B orn, M edical Malpractice Insurance in the Wake of L iability Reform, 24 J. LEG. STU D. 463 (1995).

87. CALIFORNIA MED. A SS'N \& CAL. HOSP. A SS'N, supra note 7; Troyen A. Brennan et al., Incidence of adverse events and negligence in hospitalized patients: Results of the $\mathrm{H}$ arvard $\mathrm{M}$ edical Practice Study I, 324 NEW E NG. J. MED. 370 (1991); E ric J. Thomas et al., supra note 83.

88. See L ocalio, supra note 34 .

89. See M artin v. Richey, 674 N.E .2d 1015, 1019-22 (Ind. Ct. A pp. 1997); R andall R. B ovbjerg et al., Valuing L ife and Limb in Tort: Scheduling "Pain and Suffering," 83 NW. U. L. REV. 908, 968 (1989); Frank P. Grad, supra note 85, at 1076-86; Stephen Shmanske \& Tina Stevens, The Performance of M edical Malpractice R eview Panels, 11 J. HEA LTH POL. POL'Y \& L. 525, 535 (1986); Paul C. Weiler, Fixing the Tail: The Place of Malpractice in Health Care Reform, 47 R UTGERS L. REV. 1157 (1995); Sarah G lazer, Whatever H appened to the M alpractice Insurance C risis?, W A SH. POST, J uly 9, 1991, at Z10.

90. See, e.g., B ovbjerg et al., supra note 89, at 956-58; W eiler, supra note 89, at 1180-81.

91. Lisa M. Ruda, Caps on N oneconomic D amages and the Female Plaintiff: H eeding the Warning, 44 CA SE W. RES. L. REV. 197 (1993); W. K ip Viscusi, Pain and Suffering in Product Liability Cases: Systematic Compensation or Capricious A wards?, 8 INT'L R EV . L. \& E CON. 203, 216-17 (1988). 
havior, unpredictable jury verdicts, and different (often conflicting) incentives among participants ${ }^{92}$ - limits options for cost containment. R elative to administrative approaches to compensation, the complex array of forces at work in the U .S. medical malpractice system also inhibits the system's capacity to respond uniformly and quickly to centralized reforms.

It was these concerns, coupled with anecdotal evidence about the success of tort alternatives abroad, that prompted groups of physicians, insurers, hospital administrators, and lawyers in $U$ tah and Colorado to assemble in 1992 with the objective of exploring alternatives. Baseline studies of injury rates and the economic consequences of medical injury were undertaken in order to provide data to guide the reform efforts. The remainder of this article reports on the primary objective of the economic consequences component of the studies: application of Swedish compensation criteria to actual medical injuries occurring in $\mathrm{U}$ tah and Colorado in order to estimate the costs of a no-fault compensation system in the $U$ nited States. The affordability of such a system is perhaps best judged by comparing our cost estimates to the sum of resources currently devoted to malpractice (and overall health insurance) regimes in those states.

The kinds of injury thresholds and compensation limits introduced in Sweden, N ew Z ealand, and the U nited States occupy an important position in our analyses. International trends toward higher costs of medical injury compensation suggest that use of such mechanisms in a compensation system, however designed, is critical to achieving budgetary feasibility. A ttention thus turns to the set of constraints that are best able to navigate a course between the Scylla of undue access constraint and the Charybdis of system expense. Broader questions about system design frame this challenge by influencing the range of workable constraints, and the degree to which those constraints can be leveraged effectively.

\section{COST ESTIMATES OF NO-FA ULT SYSTEM SIN UTAH AND COLORA DO}

The objectives of this study differ from those of studies focusing on estimates of the cost of medical injury in the U nited States. ${ }^{93}$ We sought to develop a model for estimating costs of a medical injury compensation system that was

92. For empirical studies of these features of the medical malpractice system, see, for example, U.S. General a CCOUNTING OfFice, Medical Malpractice: Characteristics of Closed CLA IM S IN 1984, 43-47 (1987); Samuel R. Gross \& K ent D. Syverud, G etting to N o: A Study of Settlement Negotiations and the Selection of Cases for Trial, 90 M ICH. L. REV. 319 (1991); L ocalio, supra note 34 , at 249.

93. The one exception is the New Y ork study. See William G . J ohnson et al., The E conomic Consequences of M edical Injuries, 267 J A M A 2487 (1992). H owever, that study used adverse event criteria for estimating system costs. See supra notes $10 \& 20$. Several other studies have attempted to estimate the costs of particular types of medical injuries, such as adverse drug events, using different approaches. See D avid W. B ates et al., The Costs of A dverse D rug E vents in H ospitalized Patients, 277 J A M A 307 (1997); David C. Classen et al., A dverse D rug Events in Hospitalized Patients, 277 J A M A 301 (1997); J effrey A . J ohnson \& J. Lyle B ootman, D rug-R elated M orbidity and M ortality: A Cost-ofIIIness M odel, 155 A R CH. INTER N. M ED. 1949 (1995). 
not reliant on individualized determinations of fault, which could be used by states interested in the economic feasibility of a no-fault alternative. In addition, we sought to investigate how applicable a particular set of no-fault compensation criteria, developed abroad, would be to domestic types and rates of medical injury. Planners in $U$ tah and Colorado contemplate comprehensive replacement of existing tort remedies with this type of model. ${ }^{94}$ Therefore, we chose to characterize the volume of medical injury for which compensation would potentially be made in those states according to criteria that have proven operational success in a no-fault regime. ${ }^{95}$

\section{A. M ethods}

1. Overview. This analysis was undertaken as part of a broad study of medical injury and the feasibility of a no-fault system in the states of $U$ tah and Colorado. The affordability of administrative compensation schemes in $U$ tah and Colorado was determined by estimating separately the costs of compensating all Swedish compensable events in a representative sample of injured patients, and comparing these totals to the costs of existing malpractice regimes. We also estimate the costs of compensating all adverse events due to negligence. Individuals qualifying for compensation under each of the criteria applied were eligible for an award to cover wages and fringe benefits, household production losses, health care expenses, non-economic damages, and, in cases of death, burial expenses. Levels of compensation for each qualified patient were calculated by linking the cost implications of the injury type with demographic data specific to the patient. Costs of compensating injuries to newborns and administrative expenses were estimated separately.

A fter individual awards were calculated, statewide estimates were obtained by multiplying the compensation package for each patient by his or her population weight as determined by our sampling scheme. Future costs were discounted to 1992 dollars using a real interest rate of 2.75 percent. ${ }^{96}$ We then determined the total costs for each state with four- and eight-week injury threshold periods in place, and for Swedish compensable events only.

2. Sampling and Record Review. To summarize this part of our procedure, ${ }^{97}$ we first drew a representative sample of 15,000 medical records from calendar year 1992 discharges in $U$ tah $(5,000)$ and Colorado $(10,000)$. Next, using a medical record review process, with previously studied reliability and validity, we detected two injury categories: injuries that would be compensated in a no-

94. See U tah A lliance for $\mathrm{H}$ ealth Care Inc., Project Narrative (Sept. 6, 1994) (unpublished grant application to the R obert Wood J ohnson Foundation, on file with authors); Colorado Physicians Insurance Company (Sept. 16, 1994) (unpublished submission to R obert Wood J ohnson Foundation, on file with authors).

95. See Figure 1.

96. WEILER ET AL., supra note 8 , at 89.

97. M ethods used in sampling and record review are described in detail elsewhere. See Thomas et al., supra note 83 , at 3 . 
fault system using Swedish compensation criteria and injuries that are compensable in the current tort system according to the negligence standard. ${ }^{98}$

3. D uration of $\mathrm{D}$ isability and $\mathrm{H}$ ealth $\mathrm{C}$ are $\mathrm{U}$ tilization. B efore estimating lost earnings and health care expenses, it was necessary to estimate the health care utilization of our injured patients and the period of time they would be disabled or away from work. U nlike our previous estimation of medical injury costs in N ew Y ork, ${ }^{99}$ we did not conduct interviews with a sample of injured patients to obtain this data. Instead, we adopted a two-pronged strategy. First, physician investigators reviewed each case and estimated the duration of disability, time off work, and health care utilization. Second, a panel of experienced insurance claims adjustors from each state made their own estimates. A fterwards, we met with the adjustors to discuss disagreements and reach consensus.

Duration of injury estimates are notoriously difficult to make. Even with extensive information on the patient's injury and socio-demographic background, estimates of work absence and use of the health care system are subject to margins of error. ${ }^{100}$ H owever, our strategy was supported by a number of considerations. First, this method is widely relied upon by the casualty insurance industry, including medical malpractice insurers. Second, reflecting on the experience in our $\mathrm{N}$ ew $\mathrm{Y}$ ork study, we were concerned about recall bias among patients interviewed. ${ }^{101}$ Finally, it is reasonable to expect that a no-fault compensation system would rely, at least to some extent, on this approach in making awards to patients with ongoing injury expenses. H ence, over- or underestimation of actual injury duration and service utilization for particular patients would not necessarily equate with errors in the estimation of system costs, the latter being the primary concern of our study. A fter estimating durations for disability and work absence, we were then able to proceed to calculations of other components of the compensation package: lost wages and household production, health care expenses, pain and suffering, and, in cases of death, burial expenses.

4. L ost Wages and L ost H ousehold Production. D ata sources and details of calculations for estimating each of these components of the compensation package are described in a parallel study of the costs of medical injury in U tah and Colorado. ${ }^{102}$ To assemble a standard award, we first calculated gross lost wages in all cases where a patient's injury resulted in permanent disability or death. Fringe benefits were assumed to equal twenty-seven percent of gross earnings. ${ }^{103} \mathrm{Next}$, we deducted income taxes from this total to derive net earnings loss for each injured patient in the sample (wages and fringe

98. Negligence was defined as medical care that fell below the standard expected of physicians in their community. Swedish compensable events were identified using the criteria described in Figure 1.

99. See J ohnson et al., supra note 93 , at 2488.

100. See Neil Vidmar, E mpirical E vidence on the D eep Pockets $H$ ypothesis: J ury A wards for Pain and Suffering in M edical M alpractice Cases, 43 D U KE L.J. 217, 236 (1993).

101. We have previously noted some data suggesting that patients tend to underestimate health care utilization when asked about it some time later. See J ohnson et al., supra note 93, at 2491. 
benefits). ${ }^{104}$ Lost household production was compensated for patients whose injury would prohibit or inhibit performance of domestic tasks. The duration of household production loss was assumed to be equivalent to our estimation of the time off work, and was valued using the replacement cost method (that is, the cost of hiring alternate labor to perform the tasks in question).

5. H ealth Care Costs. D etails of our health care cost calculations, including costs of inpatient care, medical equipment, pharmaceuticals, nursing home services, home health care, and physical/occupational therapy, are also provided elsewhere. ${ }^{105}$ For purposes of determining patient compensation, we assumed that a no-fault system would act as the second payor of health care costs, meeting only out-of-pocket expenses for each injured patient. We estimated that average out-of-pocket health expenditures would comprise twenty percent of total costs for each insured patient. ${ }^{106} \mathrm{U}$ ninsured patients were to be compensated in full for health care costs.

6. Consumption Deduction. For cases in which injury resulted in death, a consumption deduction was subtracted from the deceased patient's after-tax income to account for monies that would have been spent on such variable expenditures as food and clothing, but would not be consumed once the individual had died. ${ }^{107}$ In addition, it was necessary to make an analogous deduction when lost household production was compensated in death cases. The decedent's family would actually have had less total household duties to perform because the family size decreased.

7. Social Security D isability Benefit Deduction. Injured patients who were unable to work for more than twelve months because of their injury would be eligible for social security disability insurance ("SSDI"). We made a deduction

102. See Eric J. Thomas et al., Costs of Medical Injuries in Colorado and U tah in 1992 (1997) (unpublished manuscript, on file with authors).

103. See Bureau of the Census, U.S. Department of Commerce, Statistical a bstract OF THE UNITED STATES 432 (1995)

104. Income tax rates were estimated using data from the Bureau of E conomic A nalysis. In 1992, $11.8 \%$ of personal income in $U$ tah and $14.2 \%$ in Colorado was paid toward taxes levied by federal, state, and local governments. In addition, there was a $1.45 \%$ payroll tax and a $6.2 \%$ old age, survivors, and disability insurance ("OA SDI") tax on employee earnings in each state. See 1995 FEDERAL OLDA gE AND SURVIVORS INS. AND DISABILITY INS. TRUST FUNDS ANN. REP. 35-36, tbl. II.B.1. We ignored the OA SD I earnings ceiling. Thus, the average $U$ tah resident paid a total tax of $19.4 \%$, and the average Colorado resident paid $21 \%$. This percentage was deducted from each patient's gross income to determine that net income loss for each patient.

105. See Thomas et al., supra note 102, at 4-10.

106. See K atharine R. Levit et al., National Health Expenditures, 1993, HEALTH CARE FIN. REV. 247, 262 (1994).

107. The consumption deduction was calculated based on the average family size in each state ( 3.67 persons in $U$ tah and 3.07 persons in Colorado). We then applied a standard consumption formula derived from the equivalence scales published by the U.S. Bureau of Labor Statistics. This formula yielded a percentage of income spent on variable goods and services by an adult member of the average household. Since this consumption deduction was calculated as a percentage of income, the final consumption deductions were inflated with the earnings rate. 
for SSDI from the compensation package in appropriate cases. We used the 1993 average $U$ tah and Colorado SSDI benefit ${ }^{108}$ and tailored our calculations of SSD I to each patient in a manner that is consistent with prevailing eligibility requirements and restrictions. ${ }^{109}$

8. Non-E conomic Costs. Compensation for non-economic loss was calculated according to the severity of the disability attributed to the injury and to the patient's age. V alues were based on a previous analysis of jury verdict data ${ }^{110}$ adjusted to a $\$ 250,000$ cap. $^{111}$

9. Burial Expenses. For patients who died as a result of their injury, $\$ 5,000$ was compensated for funeral expenses.

10. Costs of Injuries to Newborns. Since our sample sizes in $U$ tah and Colorado were not large enough to derive a birth-related injury rate, we adapted incidence and cost estimates from an actuarial report ${ }^{112}$ that had been prepared for the Florida Birth-R elated Neurological Injury Compensation Scheme ("NICA"). The report was prepared in 1991 to estimate the total cost of claims that had been or were projected to be made to NICA between 1989 and 1993. It derived incidence rates by screening a sample of neonatal medical records in Florida according to the "no-fault" criteria used by the NICA plan. ${ }^{113}$ Rehabilitation specialists then estimated average costs of all birth-related injuries by modeling the future health care needs of the infants. Deductions were made for expenses covered by collateral sources such as Medicaid and private insurers.

We applied the NICA compensable injury rates for Florida in 1992 to the number of live births in $U$ tah $(37,200)$ and Colorado $(54,535)$ in 1992 in order to derive an estimated annual number of NICA compensable birth-related injuries occurring in $U$ tah and Colorado in 1992. This number was then multiplied by the average claim size estimate for Florida (converted to 1992 dollars)

108. These figures were $\$ 620.63$ per month in $U$ tah and $\$ 650.90$ per month in Colorado. See SO CIA L SE C. B U LL. (A nnual Statistical Supplement 1994).

109. We did not calculate deduction of these payments until five months of disability had elapsed, consistent with SSD I requirements. We deducted SSDI benefits only up to age 65. A t this age, qualified permanently disabled individuals would receive a monthly payment similar to or slightly larger than the retirement benefit they would have received without injury. If we continued to deduct full SSD I payments past retirement age, we would penalize these disabled patients.

110. See B ovbjerg et al., supra note 89 at 944.

111. See infra note 132 .

112. COOPERS \& LyBRAND, A ctuarial Study Prepared for Florida Birth-Related NEUROLOGICA L INJURY COMPENSATION A SSOCIATION (1991).

113. Three main criteria are used by NICA in determining compensability of claims. First, injured newborns must have had a birth weight greater than 2,500 grams. See FLA. STA T. A NN. § 766.302(2) (W est 1997). Second, injured newborns must have sustained permanent and substantial physical and mental impairment. See id. § 766.309(1)(a). The Coopers \& Lybrand report made this judgment using two thresholds on the Bayley Scale of I nfant D evelopment: I Q test scores of less than 50 and less than 70. See supra note 112, at 6 . Third, the injury must have been caused by oxygen deprivation or mechanical injury, not by genetic or congenital abnormality. The Coopers \& Lybrand report made this judgment using expert medical opinion. 
to derive an estimated cost of compensable newborn injury for each of the states in our study. Finally, this figure was decreased by twenty-five percent to correct partially for the degree to which the actuarial report appears to have overestimated the Florida claims rate experience. ${ }^{114}$

11. A pplication of Swedish Compensability Criteria. ${ }^{115}$ To understand how the Swedes have applied the criteria of avoidability, we traveled to Sweden and studied the methods of the Swedish claims adjustors and physicians. Working directly with adjustors and physicians, we analyzed specific cases and catalogued the principles used. Together, we reviewed actual cases from the Colorado and $U$ tah data set, and also discussed difficult cases the Swedish reviewers have encountered.

Two study investigators ${ }^{116}$ independently reviewed all medical injuries identified in our sample, and judged avoidability on a six point scale. ${ }^{117}$ Inter-rater reliability was excellent, with ninety-one percent agreement and a kappa statistic of $0.81 .{ }^{118}$ The cases in which the reviewers disagreed were discussed and consensus was reached.

12. Methodological Limitations. There are several methodological limitations to our cost estimates. First, we assumed that we were able to identify a representative sample of adverse events in each state through our review of inpatient medical records. However, some adverse events may have gone undocumented; others may have occurred exclusively in the outpatient setting. The N ew Y ork study found that few adverse events occurred or were treated exclusively in the outpatient setting ${ }^{119}$ but since the time of that study more procedures have moved to the outpatient area. To the extent such incidents did occur, we will have underestimated the costs of compensation.

Second, we assumed that all individuals who suffered a Swedish compensable event with disability lasting longer than a specified period of time (the "deductible period") would be compensated. In practice, it is extremely un-

114. See B ovbjerg, supra note 5, at 2183 n.125.

115. O ur use of Swedish criteria to determine the compensability of injuries in the $U$ tah and Colorado sample should not be confused with earlier discussion of the compatibility of the Swedish approach with predetermined categorizations of compensable injury. D eterminations were made ex post, guided by the decision framework shown in Figure 1; hence, we followed the standard approach used in Sweden.

116. Physician investigators E ric Thomas and Troyen B rennan performed this review.

117. The scale was graded as follows: $1=$ little or no evidence injury avoidable; $2=s$ light to modest

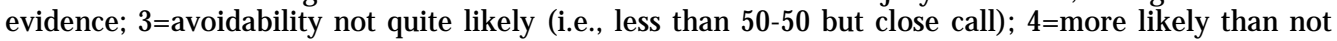
injury avoidable (i.e., more likely than $50-50$ a but close call); $5=$ strong evidence; $6=$ virtually certain evidence.

118. The kappa statistic is a widely used measure of inter-rater reliability (agreement between multiple raters of the same case), accounting for the amount of agreement that might expected by chance alone. Perfect agreement is indicated by kappa $=1$, and chance alone by kappa $=0$. A score of 0.2 or less indicates poor agreement; a score of 0.81 or greater indicates very good agreement. See J. R ichard Landis \& Gary G. K och, The M easurement of O bserver E rror A greement for Categorical Data, 33 BIOMETRICS 159 (1977).

119. See A nne C. O'Neil et al., Physician Reporting Compared with Medical-Record Review to I dentify A dverse M edical E vents, 119 A NNA LS I NTER NA L M ED. 370 (1993). 
likely that every injured patient would file for compensation. The experience of neonatal administrative schemes in Florida and V irginia reinforces that significant "underclaiming" can occur, even in a no-fault context. From one perspective, this phenomenon would tend to bias our cost estimates upward. From another perspective, if one hypothesizes that underclaiming is more prevalent in a tort model, ${ }^{120}$ it may also bias our cost estimates downward relative to the total costs of compensating all adverse events due to negligence. It is the former perspective that is relevant to our assessment of the affordability of an administrative scheme because we compare the costs of compensating all injuries eligible for compensation in the Swedish model (that is, 100 percent claiming assumption) to the actual costs of existing tort systems (that is, less than 100 percent claiming). ${ }^{121} \mathrm{H}$ ence, an overestimate of the costs of Swedishstyle systems in $U$ tah and Colorado likely stems from the claiming assumptions we made.

Third, we based awards in individual cases on the assumption that an average (working) life expectancy applied to individuals who survived medical injuries. O ur previous analyses of victims of medical injury suggest this assumption is generous, ${ }^{122}$ and total system costs may thus have been overestimated.

Fourth, we used Florida data on the incidence of birth-related injury, and its cost in the context of an existing no-fault compensation system, in order to estimate analogous costs in $U$ tah and Colorado. Some variation in the epidemiology of neonatal injury between states and over time is possible, and the costs of medical care will differ slightly between Florida, $U$ tah, and Colorado.

Fifth, we assumed that the no-fault compensation system would act as a second payor to all other existing insurance plans. It is doubtful under current law whether offsets are allowable against M edicare, M edicaid, or self-insured health insurance plans covered by the provisions of the $E$ mployee R etirement Income Security A ct. ${ }^{123}$ F ederal statutes already protect the status of these entities as second payors. ${ }^{124}$ It seems necessary, then, that any state-initiated nofault plan must secure special waivers before it is able to cut costs via collateral source offsets against these payors.

120. This hypothesis is based on the plausible assumption that, relative to patients in the tort system, patients in a no-fault system would more readily be able to identify a compensable injury and claim. Difficulties that patients (and their attorneys) appear to face in identifying and acting on instances of substandard care in the existing system have previously been noted. See W eiler et al., supra note 89 , at 1162 .

121. Underclaiming for injuries due to negligence in the medical malpractice system is no doubt offset, to some degree, by claims that are made and compensated in the absence of injury due to negligence. See L ocalio et al., supra note 34; see also Troyen A. B rennan et al., R elation B etween N egligent A dverse E vents and O utcomes of M edical M alpractice, 335 NEW ENG. J. MED. 1963 (1996). N onetheless, available evidence suggests that incidence of medical injuries due to negligence far exceeds claims. See D A NZON, supra note 1, at 19; L ocalio et al., supra note 34.

122. See WEILER ET A L., supra note 8, at 45-47.

123. See Mary A nn Chirba-Martin \& Troyen A. Brennan, The Critical Role of ERISA in State Health Reform, 13:2 HEA LTH A FF. 143 (Spring 1994).

124. See 42 U.S.C. § 1395(y) (1994) (Medicare second payer provisions); id. § 1396a (a)(25) (M edicaid third-party liability provisions); 29 U .S.C. § 1144(a) (E R ISA ). 
Sixth, our economic assumptions affected our findings: We could have used higher or lower discount, inflation, and fringe benefit rates. In addition, our estimates of household production were based on replacement cost, not the more costly opportunity cost method.

Finally, we did rely on the judgments of investigators, claims adjustors, and chart reviewers, and these judgments are clearly not immune to error.

B. R esults

1. Overview. Use of the Swedish criteria to determine compensation, provision of a moderately generous compensation package (including pain and suffering, out-of-pocket health care expenses, and wage loss), and imposition of a short deductible period would have cost approximately $\$ 40$ million in U tah and $\$ 78$ million in Colorado. These totals are larger than the costs of the current medical malpractice systems in each state- $\$ 25-30$ million and $\$ 45-50$ million, respectively-although the additional expense is equivalent to onethird of one percent of total health care costs in each state. In 1992, the approach to compensation we describe would have allowed for compensation of 1,465 victims of medical injury, more than six times the number of individuals compensated in the tort system; in Colorado, it would have permitted compensation of 973 people, a three-fold increase over the number of successful tort claimants today. 
TA BLE 2

Costs COM PONENTS OF SWEDISH COMPENSA BLE EVENTS WITH 8 WEEK DEDUCTIBLE PERIOD (MILLIONS OF DOLLARS)

\begin{tabular}{|c|c|c|c|c|c|}
\hline \multirow{2}{*}{$\begin{array}{l}\text { Loss Total } \\
\text { Type Of Loss }\end{array}$} & \multicolumn{5}{|c|}{1992 D iscounted Value Of Loss (\% ) } \\
\hline & Utah & Colorado & Utal & & Colorado \\
\hline \multicolumn{6}{|l|}{ Income A nd H ousehold Production } \\
\hline G ross W age L oss & 21.35 & 31.49 & & & \\
\hline Fringe $B$ enefits & 5.47 & 7.92 & & & \\
\hline \multicolumn{6}{|l|}{ Less: } \\
\hline Taxes & -4.16 & -6.90 & & & \\
\hline Consumption Deduction & -2.36 & -3.64 & & & \\
\hline H ousehold Production & -11.63 & -7.14 & & & \\
\hline SSDI B enefit & -1.65 & -3.39 & & & \\
\hline H ousehold Production Loss & 44.02 & 52.03 & & & \\
\hline \multicolumn{6}{|l|}{ Net Income A nd } \\
\hline $\begin{array}{l}\text { H ousehold Production L oss } \\
\mathrm{H} \text { ealth Care Costs }\end{array}$ & 51.05 & 70.37 & 45.78 & (59.6) & $57.51(57.5)$ \\
\hline G ross Costs & 21.58 & 49.99 & 19.63 & & 45.12 \\
\hline \multicolumn{6}{|l|}{ Less: } \\
\hline Compensation From & & & & & \\
\hline H ealth Insurance & -17.26 & -40.00 & -15.70 & & -36.10 \\
\hline $\mathrm{N}$ et $\mathrm{H}$ ealth $\mathrm{C}$ are Costs & 4.32 & 9.99 & 3.93 & (5.1) & $9.02(9.0)$ \\
\hline \multicolumn{6}{|l|}{ O ther Compensable Costs } \\
\hline Burial Expenses & 2.08 & 1.25 & 2.08 & (2.7) & $1.25(1.3)$ \\
\hline Pain A nd Suffering & 25.00 & 32.21 & 25.00 & (32.6) & $32.21(32.2)$ \\
\hline Total Compensable Costs & 82.44 & 113.82 & 76.79 & $(100)$ & $99.99(100)$ \\
\hline
\end{tabular}

2. Components of Compensation. Table 2 illustrates all components of compensation included in our calculations for patients who suffered injuries that are compensable according to Swedish criteria. The cost estimates presented are for those injuries that resulted in at least eight weeks of disability. A deductible or threshold period is used as a device for eliminating relatively non-serious injuries from the pool of injuries eligible for compensation. ${ }^{125}$ It also has the benefit of channeling available funds to victims whose losses are least likely to be covered by other sources of coverage, such as sick pay for time lost from work. ${ }^{126}$

In U tah, the total cost of compensation for Swedish compensable events in 1992 resulting in more than eight weeks of disability was $\$ 76.79$ million. Com-

125. R ather than basing the threshold on seriousness of injury, as measured by duration of resultant disability, several other approaches may be used. For example, a minimum-award threshold may be applied, although this does not tend to eliminate nuisance or minor suits until after administrative costs are incurred. M inimum periods of hospitalization or time off work may be established, as in Sweden. A Iternatively, the threshold may be set according to levels of medical care expenditures. Each of these approaches faces potential problems of over- and under-inclusiveness. For a discussion of these problems in the context of workers' compensation, see Theodore F. H aas, On Reintegrating Workers' Compensation and E mployers' L iability, 21 G A . L. R E V . 843, 891-95 (1987).

126. We have previously noted that application of a disability threshold can be expected to confer administrative, as well as financial, benefits. Disentangling the harmful consequences of the original illness from those attributable to the medical injury itself is a problem that is most acute in the immediate post-treatment period. See WEILER ET. A L., supra note 8, at 101-03. 
pensation first comprised a net wage loss of $\$ 17.19$ million, resulting from subtracting taxes ( $\$ 4.16$ million) from gross wage loss ( $\$ 21.35$ million). Fringe benefits added $\$ 5.47$ million. N ext, we subtracted the consumption deduction ( $\$ 2.36$ million), household production for death cases ( $\$ 11.63$ million), and the offset to social security benefits in appropriate cases ( $\$ 1.65$ million). We then added compensation for household production loss. A t $\$ 44.02$ million, this figure was approximately twice as large as gross wage loss, evidence of the relatively high incidence of medical injuries among non-wage earners in $U$ tah and Colorado in 1992. ${ }^{127}$ This result can also be explained by the fact that, unlike many wage losses, household production losses are not insured. D iscounted income and household production losses totaled $\$ 45.78$ million in $U$ tah with the eight-week deductible in place; this represents slightly less than sixty percent of total compensation.

Table 2 also shows that health care costs in $U$ tah among patients eligible for compensation under the Swedish criteria were $\$ 21.58$ million. A fter collateral offset and discounting, net health care costs were $\$ 4.32$ million, 5.6 percent of total costs. Burial expenses accounted for $\$ 2.08$ million. Finally, compensation for pain and suffering totaled $\$ 25$ million, a third of the $U$ tah total.

In Colorado, the total cost of Swedish compensable events was $\$ 100$ million. $N$ et wage loss was $\$ 24.59$ million, once again the difference between gross wage loss ( $\$ 31.49$ million) and taxes ( $\$ 6.90$ million). Fringe benefits added $\$ 7.92$ million in Colorado. Subtractions were made for the consumption deduction (\$3.64 million) and household production for death cases (\$7.14 million), and for collateral offset to social security benefits ( $\$ 3.39$ million). A s in U tah, household production loss in Colorado of $\$ 52.03$ million was a substantial proportion of total losses. A fter discounting, the net income and household production loss in Colorado was $\$ 57.51$ million, slightly smaller as a proportion of all compensation than the same total in $U$ tah.

In Colorado, net discounted health care costs totaled $\$ 9.02$ million and comprised nine percent of total costs. Burial expenses were $\$ 1.25$ million. Proportionally, this figure represents less than one-half the costs of these same items in $\mathrm{U}$ tah-a finding that underscores the fact that medical injuries detected in our $U$ tah sample were generally more severe. ${ }^{128}$ Compensation for pain and suffering accounted for $\$ 32.21$ million in Colorado, or thirty-two percent of total costs.

3. Comparative Costs of Compensating Swedish Compensable Events and N egligent A dverse E vents. A pplication of severity thresholds to injuries is one way to forge a compromise between the total costs of compensation and the generosity of the eligibility criteria in an administrative compensation scheme. A nother approach is to manipulate the depth of benefits awarded to eligible claimants. Table 3 shows the impact on total costs of excluding lost household

127. See E ric J. Thomas \& Troyen A . Brennan, The Nature of A dverse E vents in Hospitalized Patients in U tah and Colorado, tbl. 7 (1998) (unpublished manuscript on file with authors).

128. Seeid. 
production and pain and suffering from the compensation package in $U$ tah and Colorado. Both have a significant impact on total costs of compensation.

TABLE 3

\section{E CONOMIC CONSEQUENCE OF A DVERSE EVENTS}

(MILLIONSOF DOLLARS*)

\begin{tabular}{|c|c|c|c|c|}
\hline \multicolumn{5}{|c|}{ Swedish Compensable E vents N egligent A dverse E vents } \\
\hline & Utah & Colorado & Utah & Colorado \\
\hline Any D isability & $(N=2,940)$ & $(N=5,919)$ & $(N=1,759)$ & $(N=3,032)$ \\
\hline Total & $\$ 90.90$ & $\$ 128.88$ & $\$ 57.48$ & $\$ 83.76$ \\
\hline Less H ousehold Production & $\$ 60.38$ & $\$ 90.55$ & $\$ 36.87$ & $\$ 57.47$ \\
\hline Less H ousehold Production & & & & \\
\hline A nd Pain \& Suffering & $\$ 27.16$ & $\$ 38.51$ & $\$ 17.05$ & $\$ 23.85$ \\
\hline$>4$ W eeks D isability & $(N=1,465)$ & $(N=1,604)$ & $(N=999)$ & $(N=896)$ \\
\hline Total & $\$ 82.55$ & $\$ 84.23$ & $\$ 52.73$ & $\$ 69.65$ \\
\hline Less H ousehold Production & $\$ 52.42$ & $\$ 52.99$ & $\$ 32.40$ & $\$ 43.85$ \\
\hline Less H ousehold Production & & & & \\
\hline A nd Pain \& Suffering & $\$ 25.22$ & $\$ 21.21$ & $\$ 15.76$ & $\$ 17.37$ \\
\hline$>8$ W eeks D isability & $(N=889)$ & $(N=973)$ & $(N=686)$ & $(N=380)$ \\
\hline Total & $\$ 76.78$ & $\$ 87.44$ & $\$ 50.43$ & $\$ 63.12$ \\
\hline Less H ousehold Production & $\$ 45.96$ & $\$ 52.18$ & $\$ 30.38$ & $\$ 37.77$ \\
\hline $\begin{array}{l}\text { Less H ousehold Production } \\
\text { A nd Pain \& Suffering }\end{array}$ & $\$ 20.96$ & $\$ 19.97$ & $\$ 14.98$ & $\$ 13.52$ \\
\hline
\end{tabular}

*A Il amounts are in 1992 discounted dollars

The total cost of compensating all Swedish events in $U$ tah was $\$ 90.90$ million. Removing household production decreased this figure to $\$ 60.38$ million, a thirty-three percent reduction. When pain and suffering compensation was also removed, the cost decreased to $\$ 27.16$ million in $U$ tah, or a further fifty-five percent. Pain and suffering alone comprised $\$ 33.22$ million (thirty-seven percent) of total cost in $U$ tah.

Table 3 also shows that the imposition of deductible periods reduces direct costs by narrowing eligibility to those patients who have sustained more serious injuries. For example, the number of injuries in $U$ tah meeting Swedish criteria with eight weeks disability was 889 , a sixty-nine percent reduction from the "all in" total of 2,940. The cost of comprehensive compensation for this subgroup was $\$ 76.78$ million, a sixteen percent reduction from the "all in" total. ${ }^{129}$ In Colorado, total cost of compensating all Swedish events was $\$ 128.88$ million. When household production is removed, this total is reduced by thirty percent, to $\$ 90.55$ million. When pain and suffering compensation is also removed, Colorado costs decrease by a further fifty-seven percent to $\$ 38.51$ million. A pplication of deductible periods in Colorado result in reductions in the number of patients compensated and total costs that are similar to those noted in $U$ tah.

129. N ote that this is the same figure for which we show incremental calculations in Table 1. 
If eight weeks of disability were required, the number of compensable cases decreased by eighty-four percent, from 5,919 to 973 , while the total costs of compensation decreased by twenty-eight percent.

In addition, table 3 also shows the results of our estimates of the costs of injuries due to negligence in $U$ tah and Colorado in 1992. Compensating all of these events would cost $\$ 57.48$ million in $\mathrm{U}$ tah and $\$ 83.76$ million in Colorado. The cumulative effect of removing household production and pain and suffering from the compensation package are shown also. In U tah, there were 686 negligently caused medical injuries with eight weeks disability, sixty-two percent less than the total number of negligent adverse events that occurred. The direct cost of compensating the 686 events, including household production losses and pain and suffering, was $\$ 50.43$ million, a twelve percent reduction on total costs with no deductible period in place.

Removing household production and pain and suffering in Colorado reduced the total cost of compensating negligent injuries by seventy-one percent, to $\$ 23.85$ million. A pplication of the eight-week deductible period reduced the number of beneficiaries by eighty-eight percent, to 380. A ttendant costs were reduced by twenty-five percent, to $\$ 63.12$ million. A Ithough there were more negligently caused injuries in $U$ tah than Colorado, costs were lower in $U$ tah due to its higher percentage of deaths from negligence (12.8 percent in $\mathrm{U}$ tah versus 6.4 percent in Colorado). Death cases were not compensated for lost household production or income.

4. Cost of Injuries to Newborns. The costs of compensating newborn injuries was estimated at $\$ 9.69$ million in $\mathrm{U}$ tah and $\$ 14.20$ million in Colorado after relevant offsets to collateral sources were made. ${ }^{130}$

\section{$\mathrm{V}$ \\ IS NO-FAULT A FFORDABLE?}

A s expected, we found that use of the Swedish approach led to higher direct costs than the negligence approach, while compensating a substantially larger number of victims of medical injury. A II Swedish compensable events in U tah and Colorado in 1992 could be compensated for \$219.78 million, compared to $\$ 141.24$ million for negligent events only. H owever, this larger budget generated by use of the Swedish criteria compensated twice the number of injured patients.

However, these are grand totals, and, as such, they provide theoretical rather than practical estimates of the total cost of a no-fault approach to medical injury compensation. Through examination of the Swedish and New Zealand experiences, and by refining our own estimates, we have highlighted the importance of standard cost containment devices to any compensation scheme that will be both workable and affordable. Total costs of a no-fault system

130. O ffsets were made in the Coopers \& L ybrand report, supra note 112 , at 27. 
should be estimated using these devices, and compared to the status quo as a neutral test of affordability.

\section{A. Designing A ffordable No-F ault}

$U$ se of a deductible period decreased the number of claimants in our models and directed funds to the most severely injured patients. Decreases in administrative costs associated with claims compensation can also be expected after deductible periods are used to narrow the body of injuries eligible for adjudication. A dditionally, our incremental calculations in tables 2 and 3 emphasize the significant impact of household production losses, and of pain and suffering, on total system costs. O mission or limited inclusion of these particular benefits from the no-fault award is not an unreasonable approach, at least on the strength of comparison to compensation available from existing tort or administrative no-fault systems in the U nited States. Workers' compensation schemes rarely provide benefits for lost household production or pain and suffering, and deductible periods are typically set down as prerequisites to recovery. ${ }^{131}$ M oreover, while a number of states have resisted legislating caps on noneconomic damages, $U$ tah and Colorado already have $\$ 250,000$ caps in place for all malpractice awards. ${ }^{132}$

M ore importantly, the use of injury thresholds and careful consideration of the content of awards can constrain system budgets without necessarily jeopardizing the key advantages of a no-fault approach. ${ }^{133}$ R ealization of a no-fault system's primary objective-securing wider opportunities for victims of medical injury to be compensated for their losses-is not incompatible with placing limitations on compensable medical injury. For example, when we applied Swedish criteria and a four-week deductible period to medical injuries in Colorado, the number of compensable injuries decreased from 5,919 to 1,604, a seventy-three percent reduction. Nonetheless, twice the number of patients remained eligible for compensation than was the case with application of the same deductible period to the negligence model.

A second anticipated benefit of the no-fault model is efficiency. R educing costs of delivering compensation to eligible patients is a crucial goal of any reform of the fault-based compensation system. A dministrative costs associated with a no-fault medical compensation system are expected to be higher than the twenty cents of every claims dollar spent on administration in workers' compensation plans, ${ }^{134}$ but substantially lower than the fifty-five cents of every claims dollar spent on administration (primarily to offset legal expenses) in the

131. See J oseph H. King, J r., The Exclusiveness of an E mployee's Workers' Compensation R emedy A gainst $H$ is E mployer, 55 TENN. L. REV . 405, 408 (1988).

132. SeeUtAh CODE A NN. § 78-14-7.1 (1986); Co. ReV. StA T. § 13-64-302, (1)(1995).

133. A recent analysis of the Swedish, Finnish, and New Zealand no-fault schemes suggests that cost constraints in such administrative compensation systems are best pursued by eliminating damages for pain and suffering and for the first one or two months of lost income. See DON DEWEESET AL., EXPLORING THE D OMA IN OF A CCIDENT LA W: TA KING THE FA CTS SERIOU SLY 428-29 (1996).

134. See G eorge L. Priest, The Current Insurance Crisis and M odern Tort L aw, 96 Y A LE L. J . 1521, 1560 (1987). 
existing medical malpractice system. ${ }^{135}$ In our earlier N ew Y ork study, we suggested that thirty percent of every claims dollar is a reasonable estimate for the proportion of system costs likely to be devoted to administrative overhead in a no-fault model. ${ }^{136}$

O ne way that use of the Swedish approach to compensation could realize efficiency gains is through adoption of qualifying circumstances for a wide array of compensable events, thereby simplifying the decisionmaking processes associated with compensation. These definitions would play the same role as accelerated compensation events, as discussed earlier. ${ }^{137}$ Such uniformity of decisionmaking is critical to an effectively functioning administrative no-fault scheme. $^{138}$

What compensation criteria will actually be used in states contemplating the introduction of no-fault? In U tah, one approach to compensation being considered by planners would use Swedish compensable events, require a fourweek disability period, place a $\$ 100,000$ cap on pain and suffering, not include household production, and allow sixty-six percent wage replacement. When estimates are added to account for both administrative expenses (thirty percent) and the costs of birth-related injury, we calculate total system costs in U tah of $\$ 54.9$ million (1992 dollars). In Colorado, the preferred model involves use of Swedish compensable events, requires eight weeks of disability, and does not include household production. The estimated costs of this program, again after addition of administrative and birth injury costs, total $\$ 82.0$ million (1992 dollars).

\section{B. No-F ault V ersus Tort Costs}

A reasonable way to judge the "affordability" of these estimates is to compare them to the costs of the tort system currently operating in each state. To derive the cost of malpractice systems in $U$ tah and Colorado, we gathered information on total premiums paid by providers and hospitals. B ased on information from the largest physician and hospital insurers, including self-insurers, in each state, we estimated the total malpractice premiums to be $\$ 100-110$ million (1992 dollars) in Colorado and $\$ 55-60$ million in $U$ tah. Thus our cost estimates for the Swedish-style systems under consideration in $U$ tah and Colorado compare favorably to these current expenditures: at $\$ 54.9$ million, the U tah model would cost about the same as the tort system, while at $\$ 82.0$ million, the Colorado model would actually be expected to reduce the costs of compensating medical injury by $\$ 18-28$ million annually. To keep these additional costs in broader perspective, 1992 total personal health care expenditures were $\$ 3.8$ billion in $\mathrm{U}$ tah and $\$ 9.4$ billion in Colorado. ${ }^{139}$

135. See James S. Kakalik \& Nicholas Pace, Costs and Compensation Paid in Tort LITIGATION 71 (1986).

136. See WEILER ET A L., supra note 8, at 106.

137. See supra notes $12-17$ and accompanying text.

138. See $L$ ocalio et al., supra note 18 , at 463 .

139. K atharine R. Levit et al., State Health Expenditure A ccounts: B uilding B locks for State H ealth 
The corollary to the above cost estimates is the number of patients who are compensated under alternate systems. When no-fault and tort are compared on this measure, dramatic differences are apparent. In $\mathrm{U}$ tah, with a four-week deductible period, the model under consideration would allow compensation to flow to approximately 1,465 injured patients, as opposed to the estimated 210240 successful claimants today. ${ }^{140}$ In Colorado, with an eight-week deductible period, 973 would be eligible for compensation, compared to approximately 270-300 claimants today. In sum, costs of the preferred no-fault programs in $\mathrm{U}$ tah and Colorado are comparable to costs of the current medical malpractice systems in those states.

The above comparisons are somewhat sensitive to the assumptions about claiming behavior that underlie our estimates. A s noted earlier, both the costs of the no-fault models, and the number of patients we describe as "compensated" by them, are based on injury occurrence. Therefore, it is implicitly assumed that all eligible injuries result in compensation. In reality, however, some proportion of the patients who suffer compensable injury will not claim, particularly in the case of less-severe injuries. O ur estimates of malpractice costs in $U$ tah and Colorado, on the other hand, are based on premiums and so capture the actual claims rate. O ne effect of this difference is to bias upward our estimates of the costs of no-fault; the other effect is to inflate the difference between numbers of injured patients who benefit from compensation in each system. ${ }^{141} \mathrm{~N}$ onetheless, even under the very conservative assumption that the no-fault models deliver compensation to only one-half of eligible cases, U tah's compensated population would still increase three-fold and Colorado's would nearly double.

\section{VI}

\section{CONCLUSION}

D issatisfaction with the medical malpractice system in the U nited States has generated much discussion of alternatives over the last twenty-five years. Meanwhile, two OECD nations-Sweden and New Zealand-have spent this

Spending A nalysis, 17 HEA LTH CARE FIN. REV. 201 (1995).

140. A study of claiming behavior in $U$ tah and Colorado has calculated approximately $350-400$ claims in U tah annually and approximately 450-500 claims in Colorado annually. D avid M. Studdert et al., Suing for Medical M alpractice in U tah and Colorado in 1992 (1998) (unpublished manuscript on file with authors). We have assumed that $60 \%$ of these are successful-a generous assumption in light of empirical evidence about the success rate of plaintiffs in medical mal practice litigation.

141. We cannot be certain whether the phenomenon of underclaiming would result in system cost decreases that were proportionately equivalent to decreases in the number of patients compensated. This would depend on the average cost of injury among underclaimants compared to the average cost of injury among the statewide pool of injured patients. It is reasonable to expect that cost decreases would actually be proportionately less, since a higher incidence of underclaiming seems likely among less seriously injured patients (i.e. those with less than average expected compensated costs). These patients are likely to have greater difficulty in detecting their injury for purposes of bringing a claim. In addition, the transaction costs of bringing a claim are more likely to exceed expected gains from a claim among these patients. 
same period accumulating considerable experience in the operation and refinement of an administrative approach toward compensating patients for medical injuries. The experience from abroad provides opportunities for more focused examination of alternatives to the A merican tort system. By applying those al ready developed no-fault compensation criteria, while taking account of competing considerations of equity and cost, one can make a credible assessment of the viability of no-fault compensation in the $U$ nited States.

We applied the Swedish approach to compensation to a sample of medical injuries from $U$ tah and Colorado in order to add new empirical data to the debate about the affordability of a no-fault system. O ur results provide statespecific data that are otherwise unavailable to policy-makers in $U$ tah and Colorado who are considering the implementation of no-fault medical injury compensation systems. We conclude that adoption of a Swedish-style approach could lead to a system that is both affordable and positioned to compensate a considerably larger proportion of medically injured patients than the current malpractice system manages or even allows.

To some degree, our estimates of affordability rely on such design features as disability thresholds, caps on pain and suffering, and some restrictions on the extent of allowable benefits. U se of such design features to contain costs is compatible with application of no-fault criteria, a fact sometimes overlooked by no-fault skeptics. ${ }^{142} \mathrm{R}$ ather, efforts to channel available funds to the most severely injured, and to impose limits on the size of awards, appear to be a widely adopted response to the rising costs of compensation. A nalysis of tort alternatives in this context, therefore, actually squares cost estimates with the social, economic, and political realities of the day.

The results of our analyses should be encouraging for states that are contemplating an experiment with a no-fault approach to medical injury compensation. However, we certainly do not conclude that a Swedish model is neatly transplantable. A number of features of the Swedish model can be expected to present problems in the A merican environment. For example, the Swedes maintain a tort option alongside the no-fault claims process. In the $U$ nited States, where considerably fewer public benefits are available to defray the costs of injuries and propensity to sue appears to be unrivaled, ${ }^{143}$ exclusivity of no-fault relief within fixed geographical, provider, or injury parameters would seem crucial to its (financial) viability.

In addition, it is unclear how patients would respond to implementation of a no-fault system. While data suggest that rates of medical injury are fairly constant across time and locations, claiming behavior in the dynamic U.S. envi-

142. See, e.g., M atthew K. R ichards, The U tah M edical No-Fault Proposal: A Problem-Fraught Rejection of the Current Tort System, I BY U L. R EV. 103 (1996); J eff G ooch, Is M edical Industry Setting Up Utah?, SA LT LAKE TRIB., Feb. 9, 1997, at A A 7.

143. See, e.g., Frances H. M iller, M edical M alpractice L itigation: Do the B ritish $\mathrm{H}$ ave a B etter Remedy?, 11 A M. J. L. \& M ED. 443 (comparing propensity of patients to sue for medical malpractice in the U nited States and G reat B ritain), see also PA LMER, supra note 58, at 43. 
ronment is recognized to be highly unpredictable. ${ }^{144}$ We predict the degree of "underclaiming" identified in the tort system would not be likely to occur if the negligence requirement is removed, particularly if motivation among providers to conceal medical injuries from patients can be mitigated and lawyerless avenues to compensation are established.

Finally, it is unclear how a no-fault system would perform in meeting other important objectives of an injury compensation system. Will efficiency goals be realized? Can data collection, prevention efforts, and quality improvement be enhanced after removal of fault-based approaches? Will no-fault systems achieve the popularity in the U nited States that they appear to enjoy abroad? A nswers to these questions await the implementation of demonstration projects.

144. See, e.g., L ocalio, supra note 34 , at 249. 